\title{
The Economic Sanctions against Russia: Impact and Prospects of Success
}

\author{
Susanne Oxenstierna \& Per Olsson \\ Stockholm: FOI 2015 \\ 88 sider. ISSN 1650-1942
}

\begin{abstract}
Anmeldt af Mette Skak [PhD, lektor, Institut for Statskundskab, Aarhus Universitet, msk@ps.au.dk]
\end{abstract}

Det svenske forsvars forskningsafdeling FOI offentliggør mange læseværdige analyser af russiske forhold, denne er en i rækken. Emnet gør den til lidt af et pionerarbejde: Det drejer sig om at kulegrave effekten de økonomiske sanktioner, som EU og USA indførte mod Rusland efter annekteringen af Krim, dvs. navnlig de egentlige sektorsanktioner, der fulgte oven på de russisk-støttede Donbas-separatisters nedskydning af et malaysisk passagerfly i juli 2014. Brødanalysen består af fire kapitler, der dels går nærmere ind på EU's og USA's sanktioner, dels præsenterer en analysemodel og et mere komparativt perspektiv på sanktioners effekt ud fra erfaringerne fra sanktionerne mod Sydafrika, Libyen og Irak, dels en analyse af Ruslands økonomiske situation og dels en afsluttende SWOT-analyse af de styrker, svagheder, muligheder og trusler, som det internationale samfund står med i denne sag.

Så det er et særdeles lødigt analysearbejde, man som læser sidder med i hånden. Analysemodellen understreger samspillet mellem det internationale samfund, den regering, der er målet for sanktionerne, og dens samspil med dens eget indenrigspolitiske bagland. Sidstnævnte relation er kritisk for om sanktionerne får effekt. Effekten af sanktioner hænger endvidere sammen med de omkostninger, de skaber; modtagerens handelsafhængighed, sanktionernes varighed og så videre. Ikke mindst tidsfaktoren - det internationale samfunds vedholdenhed - er afgørende. I Sydafrika gik der 50 år, før gennembruddet kom, og i Irak lykkedes den økonomiske pression mod Saddam Hussein aldrig. Dette komparative perspektiv og forfatternes ledsagende »Lessons learned" er meget velgørende, og den afsluttende SWOT-analyse systematiserer væsentlige sider ved den russiske case.

Alligevel har jeg en vigtig anke mod forfatternes konklusion på analysen, der hviler på nogle alt for formalistiske succeskriterier. I det svenske resumé hedder det ganske ureflekteret om sanktionerne, at »de hittils inte har lyckats övertyga Ryssland om att ändra sin politik gentemot Ukraina«. Ganske rigtigt har Rusland ikke annulleret annekteringen af Krim og Ruslands politik mod det øvrige Ukraine veksler mellem lavintens krigsførelse fra Donbas og grov økonomisk-politisk chikane. Ikke desto mindre kulminerede den russiske offensiv mod Ukraine i tiden efter nedskydningen af MH17 og har gennem det seneste halvandet år bestået i en anderledes forsigtig 
fremfærd samt en afledningsmanøvre - den pludselige indgriben i Syrien. Vi ved, at Kreml er meget optaget af mulige sprækker i enigheden mellem EU og USA om at opretholde sanktionsregimet og meget gerne så det sløjfet. Mange sikkerhedspolitisk sagkyndige mener, at sanktionerne har været et klogt og slagkraftigt svar på Ruslands brud på folkeretten. Det er sjældent, at kritikerne har et brugbart forslag til, hvad alternativet skulle være.

Som antydet slår forfatterne ned på samspillet mellem Kreml og det russiske civilsamfund, hvor de pointerer, at regeringspropagandaen fordrejer, hvad det er, der skaber de økonomiske vanskeligheder i landet. Kreml har haft held til at gøre sanktionerne til en forventelig kold krig fra Vestens side at dømme efter den Putineufori eller apati, der præger Rusland. Men det er naivt at tro på opbakningen bag Putin, den er en tynd fernis af politisk korrekthed parret med troen på, at Putin er »den mindst ringe «. Hans seneste tale til Ruslands føderale forsamling dvælede mest ved økonomien, mens Ukraine nærmest blev forbigået i tavshed; hvad der synes forårsaget af behovet for at krisestyre indadtil. Putin og hans inderkreds af siloviki og ikke-siloviki udgør jo ikke et decideret folkemorderisk autoritært styre såsom Baath-styret i henholdsvis Syrien og i sin tid Irak. Det betyder, at Kreml har mindre indenrigspolitisk handlerum end som så (hermed ikke sagt, at Putins dage ved magten er talte).

Faktisk dokumenterer forfatterne selv, at end ikke forsvarsbudgettet går ram forbi (s. 41), hvad der givetvis udgør en smertelig nedskæring for det ny-militaristiske Rusland - ergo et vidnesbyrd om, at sanktionerne bider. Det kan her indvendes, at den afgørende faktor bag den igangværende økonomiske krise i Rusland er det dramatiske fald i oliepriserne, ikke sanktionerne, som kun står for »en tredjedel « af miseren. Men selv med denne afgørende præcisering forbliver analysens hovedkonklusion ret absurd. Perspektivet for sanktionerne mod Rusland er formentlig, at selv hvis det skulle komme til en vis afvikling af dem, vil man opretholde forbuddet mod militære eksporter på samme måde, som EU har gjort våbenembargoen mod Kina til den nye normal i dette bilaterale forhold. Generelt er der tale om velvalgte sektorsanktioner henholdsvis adgangen til refinansiering af de russiske strategiske virksomheders gæld og adgangen til arktisk olieboringsteknologi ud over de nævnte militære sanktioner. Hertil kommer en de facto-sanktion, der altid overses, nemlig at Ukraine-dramaet satte en stopper for Ruslands optagelse i den vestlige økonomiske samarbejdsorganisation OECD. Måske er det den »sanktion«, man i givet fald først skulle fire på? Et russisk medlemskab af OECD ville forudsætte vilje til at skabe transparens i økonomien; omvendt gælder det, at en optagelse i OECD ville hjælpe med at genopbygge den tillid blandt udenlandske investorer, som Rusland har akut brug for.

Oxenstierna og Olssons analyse af den økonomiske situation i Rusland kan varmt anbefales, den er spækket med information og kildehenvisninger. De drøfter det russiske modtræk til sanktionerne, det tilsyneladende omsving til en importsubstitutionsstrategi som udløber af Putins fødevareembargo mod Vesten fra august 2014 (ikke april, som det står s. 60). Givet Ruslands høje importafhængighed er en sådan strategisk kovending et rent selvmål. Under overskriften »Gosplan revisited?« omtales det nye koordinationscenter for store indkøb, som Dumaen lovgav om i april 2015, men som de statslige olieselskaber ikke vil finde sig i. Analysen af de russiske 
bestræbelser på at omdirigere udenrigshandelen i nye geografiske retninger understreger den massive forringelse af bytteforholdet, som Rusland er havnet i. Mest markant over for Kina, det er de hårde realiteter bag det nære russisk-kinesiske forhold. Forfatterne gør det klart, at det, der set udefra er et irrationelt fravær af nødvendige reformer, er set gennem Putins briller et spørgsmål om at tilgodese de russiske rent-seekers, det vil sige den koalition, som hans magt hviler på. Selvsagt lægger koalitionen begrænsninger på, hvor langtidsholdbar den russiske økonomiske model er, men det er en helt anden historie. 